\title{
Percepção da fala em deficientes auditivos pré-linguais usuários de implante coclear****
}

\author{
Speech perception in pre-lingual deaf users of cochlear implant
}

\author{
Thais Corina Said de Angelo* \\ Maria Cecília Bevilacqua** \\ Adriane Lima Mortari Moret***
}

*Fonoaudióloga. Especialista em Audiologia Clínica e Educacional pelo Hospital de Reabilitação de Anomalias Craniofaciais (HRAC) da Universidade de São Paulo (USP). Fonoaudióloga do Departamento de Fonoaudiologia da Faculdade de Odontologia de Bauru (FOB) da USP. Endereço para

correspondência: Av. Orlando Ranieri, 7-108 - Apto. 4 - Bloco 24 - Bauru - SP - CEP 17047-001

(thathasaid@yahoo.com.br).

**Fonoaudióloga. Professora Titular do Departamento de Fonoaudiologia da FOB - USP.

***Fonoaudióloga. Doutora em Ciências - Distúrbios da Comunicação Humana pelo HRAC - USP. Docente do Departamento de Fonoaudiologia da FOB-USP.

****Trabalho Realizado no Centro de Pesquisas Audiológicas (CPA) do HRAC - USP.

Artigo Original de Pesquisa

Artigo Submetido a Avaliação por Pares

Conflito de Interesse: não

Recebido em 15.07.2009.

Revisado em 17.06.2010; 15.07.2010. Aceito para Publicação em 16.08.2010.

\section{Abstract}

Background: cochlear implant is a rather processing electronic device in terms of its benefits, as it provides the deaf child with the appropriation of incidental oral language. Aim: to evaluate the hearing performance of the first 60 children with pre-lingual sensorineural hearing loss who were implanted at the Audiologic Research Centre of the Hospital de Reabilitação de Anomalias Craniofaciais of the University of São Paulo (CPA-HRAC/USP), 16 years after the implementation of the cochlear implant programme. Method: 57 children aged between 9 and 18 years were evaluated using the following speech perception tests: lists of monosyllabic and disyllabic word recognition; lists of meaningless syllables recognition Consonant Confusion Study - Confuse Program (presented in the System to Deploy Cochlear Nucleus software in its programming unit - version 6.90); lists of sentence recognition and list of words used for the assessment of speech sound perception for children with hearing impairment. Results: all children achieved satisfactory results with the cochlear implant. In the tests involving the index of phoneme and word recognition, the results were statistically significant for the type of cochlear implant Med-El when compared to the other types of implants. Conclusion: the study indicates that the cochlear implant has brought real benefits for the group of studied children, as it allowed the maximum development of the auditory skills.

Key Words: Speech Perception; Hearing Loss; Cohclear Implantation.

\section{Resumo}

Tema: o implante coclear é um dispositivo eletrônico bastante promissor quanto aos benefícios, já que proporciona para a criança surda a apropriação da linguagem oral incidental. Objetivo: avaliar o desempenho de audição do grupo das 60 primeiras crianças com deficiência auditiva neurossensorial pré-lingual implantadas no Centro de Pesquisas Audiológicas do Hospital de Reabilitação de Anomalias Craniofaciais da Universidade de São Paulo (CPA-HRAC/USP), após 16 anos de funcionamento do programa de implante coclear. Método: foram avaliadas 57 crianças com idades entre 9 e 18 anos, utilizando os seguintes testes de percepção de fala: listas de reconhecimento de vocábulos monossílabos e dissílabos; listas de reconhecimento de sílabas sem sentido - Consonant Confusion Study - Confuse Program (apresentado no software do Sistema de Implante Coclear Nucleus, na sua unidade de programação versão 6.90); listas de reconhecimento de sentenças e lista de palavras como procedimento de avaliação de percepção dos sons da fala para crianças deficientes auditivas. Resultados: todas as crianças obtiveram resultados satisfatório com o implante coclear. Nos testes para o índice de reconhecimento de fonemas como para o reconhecimento de palavras, os resultados foram estatisticamente significante para o tipo de implante coclear Med-El em comparação com os demais tipos de implante. Conclusão: o estudo revela que o implante coclear trouxe benefícios reais para o grupo de crianças estudado, uma vez que possibilitou o desenvolvimento máximo das habilidades auditivas.

Palavras-Chave: Percepção da Fala; Deficiência Auditiva; Implante Coclear. 


\section{Introduction}

Hearing impairment is characterized by sensory deprivation and its consequences affect the development of hearing and oral language, and may have emotional, educational, social and cultural implications1.

The treatment of hearing loss in children involves the use of electronic devices applied to impairment. In the nineties, cochlear implants were widely used in children, proving to be an effective resource to minimize the consequences of hearing loss, improving therefore, the quality of life of these individuals2-4.

Literature has reported the benefits that Cochlear implants have brought to deaf children, being highly effective in treating hearing loss, in spite of its complexity due to the interaction of variables that interfere with the child's performance5-6.

One of the variables to be considered is the child's age at the time of surgery. Several studies have shown that children who received their implants at an early age have better hearing, incidental language appropriation and intelligibility7-11. Regarding the type of implant, it is observed that this aspect is closely related to how long the device has been used, the length of deafness, and the speech coding strategy. The etiology of deafness doesn't seem to interfere with the performance of the implanted children 5

How long the device has been used has also been relevant in the results obtained in children1213. In a prospective longitudinal study conducted with 30 implanted children for a period of 10-14 years, speech perception and intelligibility were assessed. The results showed that $87 \%$ of children used the implant effectively and after 10 years of use, $60 \%$ achieved category 7 in the Categories of Auditory Performance (CAP) Scale, and 77\% developed intelligibility14 and speech similar to those with no hearing impairment.

Due to the results shown, cochlear implants appear to be quite promising with regards to benefits, since they provide appropriation of incidental language for the deaf child, something that did not occur or occurred very little before this resource.

At the Centro de Pesquisas Audiológicas at the Hospital de Habilitação de Anomalias Craniofaciais , Universidade de São Paulo (CPA-HRAC/USP), all children who underwent cochlear implant surgery in this institution have follow up visits.
This work aimed to study the hearing performance of the first 60 implanted children at CPA-HRAC/USP who had prelingual sensorineural hearing impairment after 16 years of the cochlear implant program. The results will enable scientific analysis of this program for children.

\section{Method}

This study was approved by the Ethics Research Committee (Comitê de Ética em Pesquisa - CEP) of the HRAC / USP, under the number 070/2009 SVAPEPE / CEP. All of participants signed the Informed Consent Form in order to participate in the research.

\section{Subjects}

The study was conducted with 57 out of the 60 individuals from the group of prelingual hearing impaired children subjected to cochlear implant surgery according to institutional criteria of selection proposed by the CPA / HRAC5. Three out of the 60 subjects were not evaluated because two did not return to the annual follow-up visit, even after several attempts to contact them; one individual, with partial electrode insertion, presented complications after a few years, making the removal of the internal component of the implant necessary.

The age of the subjects studied in the evaluation ranged from 9:2 to 18:2. The length of sensory deprivation ranged from 1:8 to $6: 3$, and the use of the cochlear implant ranged from 6:10 to 13:11. All 57 subjects had full insertion of the electrodes.

\section{Material}

The procedure for assessing the perception of speech sounds were: lists of recognition of monosyllabic and disyllabic words15; lists of recognition of nonsense syllables - Consonant Confusion Study - Confuse Program (presented in the software of the Cochlear Implant System Nucleus, in its programming unit - version 6.90); lists of sentence recognition number 116 and list of words used as assessment procedure of speech sound perception for hearing impaired children 17. For some procedures the free-field system with the Midimate 622 audiometer, a digital compact disc (CD) developed by Auditec Saint Louis, 1997, and Teac PD-P30 CD Player-Compact Disc Audio were needed. 
Methodology

The speech evaluation procedure of list of words as assessment procedure of speech sound perception for hearing impaired children and the list of sentences were applied in acoustic booths, over the speakers, free-field system, at an intensity of $60 \mathrm{~dB}$, selected by the audiometer calibrated at $100 \mathrm{~dB}$ NA. The speakers were positioned at a $45^{\circ}$ Azimuth angle, $60 \mathrm{~cm}$ away from the child's ear and sound output presented to the same side as the implanted ear.

The other procedures were performed in the same conditions as above; however, speech was applied using the digital compact disc connected to the audiometer through the CD Player. For the presentation of the speech, stimulus intensity of $60 \mathrm{~dB}$ was used. All procedures were applied in all individuals and the results are offered in percentile and could be compared statistically.
The procedures were selected in both easier levels, like those applied to children, and in harder levels, like those designed for adults. We chose to apply all procedures to all children to verify how they would perform in various types of tests.

Data analysis

In order to compare the results obtained in procedures for assessing speech perception and different types of implant, the model one-way analysis of variance was used. In order to make the post hoc comparisons, Turkey's correction was used 18.

\section{Results}

Table 1 shows the distribution of 57 subjects studied in regards to age, length of sensorial hearing deprivation and length of cochlear implant usage.

Table 2 shows the comparison between the results of speech perception tests with types of cochlear implant of the group of 57 subjects studied.

TABLE 1. Distribution of individuals studied in regards to age, sensorial hearing deprivation and length of cochlear implant use.

\begin{tabular}{|c|c|c|c|c|c|c|c|}
\hline Variable & Type of Implant & $\mathrm{N}$ & Mean & Standard Deviation & Minimum & Median & Maximum \\
\hline \multirow{3}{*}{ age } & Nucleus-22 & 24 & 14 y $11 \mathrm{mo}$ & 1 y $11 \mathrm{mo}$ & 11 y 3 mo & 15 y 3 mo & $\begin{array}{c}18 \text { y } 2 \\
\text { mo } \\
14 \text { y } 3\end{array}$ \\
\hline & Nucleus-24 & 18 & 12 y 7 mo & $10 \mathrm{mo}$ & $11 \mathrm{y}$ & $\begin{array}{c}12 \text { y } 7 \text { mo } \\
12 \text { y } 10\end{array}$ & $\begin{array}{c}\text { mo } \\
12 \text { y } 8\end{array}$ \\
\hline & Med-El & 15 & 10 y $11 \mathrm{mo}$ & 1 y $2 \mathrm{mo}$ & 9 y 2 mo & mo & mo \\
\hline \multirow{3}{*}{$\begin{array}{l}\text { hearing } \\
\text { sensorial } \\
\text { deprivation }\end{array}$} & Nucleus-22 & 24 & 3 у 10 mo & 1 y 2 mo & 1 y 9 mo & 3 y 10 mo & 6 y 3 mo \\
\hline & Nucleus-24 & 18 & 3 y 7 mo & $9 \mathrm{mo}$ & 2 y 3 mo & 3 y $7 \mathrm{mo}$ & 5 y 6 mo \\
\hline & Med-El & 15 & 3 y 1 mo & $1 \mathrm{y}$ & 1 y $8 \mathrm{mo}$ & $3 y$ & 4 y $9 \mathrm{mo}$ \\
\hline \multirow{3}{*}{$\begin{array}{l}\text { length of time } \\
\text { using the } \mathrm{Cl}\end{array}$} & Nucleus-22 & 24 & 10 y $11 \mathrm{mo}$ & 1 y 2 mo & $9 \mathrm{y}$ & 10 y 6 mo & $\begin{array}{c}13 \text { y } 11 \\
\text { mo } \\
10 \text { y } 6\end{array}$ \\
\hline & Nucleus-24 & 18 & 8 y 11 mo & $8 \mathrm{mo}$ & 7 y 9 mo & 8 y 11 mo & mo \\
\hline & Med-El & 15 & 7 y 7 mo & $5 \mathrm{mo}$ & 6 y 10 mo & 7 y 7 mo & 8 y 4 mo \\
\hline
\end{tabular}


TABLE 2. Results of the comparison between the speech perception tests and implant types.

\begin{tabular}{|c|c|c|c|c|}
\hline \multirow{2}{*}{ Test } & \multirow{2}{*}{ Type of Implant } & \multirow{2}{*}{$\begin{array}{l}\text { Estimated } \\
\text { Mean }\end{array}$} & \multicolumn{2}{|c|}{ Confidence Interval (95\%) } \\
\hline & & & Inferior Limit & Superior Limit \\
\hline \multirow{3}{*}{$\begin{array}{l}\text { monosyllables - } \\
\% \text { of correct answers }\end{array}$} & Nucleus - 22 & 40 & 30 & 51 \\
\hline & Nucleus - 24 & 48 & 36 & 60 \\
\hline & Med - El & 47 & 34 & 61 \\
\hline \multirow{3}{*}{$\begin{array}{c}\text { disyllables - } \\
\% \text { of correct answers }\end{array}$} & Nucleus - 22 & 45 & 33 & 57 \\
\hline & Nucleus - 24 & 54 & 40 & 67 \\
\hline & Med - El & 54 & 39 & 68 \\
\hline \multirow{3}{*}{$\begin{array}{l}\text { nonsense syllables - } \\
\% \text { of correct answers }\end{array}$} & Nucleus - 22 & 35 & 24 & 46 \\
\hline & Nucleus - 24 & 47 & 34 & 60 \\
\hline & Med - El & 43 & 30 & 57 \\
\hline \multirow{3}{*}{$\begin{array}{c}\text { sentences - } \\
\% \text { of correct answers }\end{array}$} & Nucleus - 26 & 36 & 23 & 50 \\
\hline & Nucleus - 28 & 47 & 31 & 62 \\
\hline & Med - El & 48 & 31 & 65 \\
\hline \multirow{3}{*}{$\begin{array}{c}\text { phonemes - } \\
\% \text { of correct answers }\end{array}$} & Nucleus - 30 & 72 & 64 & 81 \\
\hline & Nucleus - 32 & 83 & 73 & 93 \\
\hline & Med - El & $90 *$ & 80 & 100 \\
\hline \multirow{3}{*}{$\begin{array}{c}\text { words - } \\
\% \text { of correct answers }\end{array}$} & Nucleus - 34 & 56 & 45 & 66 \\
\hline & Nucleus - 36 & 69 & 56 & 81 \\
\hline & Med - El & $78^{*}$ & 65 & 92 \\
\hline
\end{tabular}

$\left.{ }^{\star}\right)$ Statistically significant $(p<0,05)$.

\section{Discussion}

The best results were obtained on the last test - recognition of words and phonemes, as it corresponds to a procedure developed specifically for children, consisting of words that are part of a child's everyday vocabulary.

As for age at the time of the evaluation, it was noted that the older subjects and with the longest hearing sensorial deprivation are in the hearing impaired cochlear implant users group Nucleus 22 (Table 1). This is justified, since in the beginning of the CPA/USP Cochlear Implant Program, the selection criteria for surgery was children older than 3 years old and the implantation started with the Nucleus 22 implant. Comparing the performance in the speech perception tests (Table 2), we observed that there was lower performance of these subjects, which may be related to the length of the sensorineural hearing loss, since literature indicates that this really affects the performance of the prelingual implanted subjects7-9.
The performance in the speech perception assessment procedures in relation to the different types of implants was statistically significant for the Med-El model compared with other models, both for word recognition and recognition of phonemes17 (Table 2).

The results were not the same as those found in a study that evaluated the speech perception of cochlear implant users with 3 different brands of implant19. Considerable progress was observed in speech perception ability, regardless of the cochlear implant type19.

In another study aimed at evaluating the speech perception abilities among users of two types of cochlear implants (Med-El and Nucleus 24), the results showed better

performance with the model Med-El C40 +, which can be explained by the different CIS signal processing, which emphasizes temporal information in speech 20. 
This research demonstrated satisfactory performance of the subjects studied (Table 2) in the speech perception tests applied, agreeing with the literature4. A study14 assessed speech perception in implanted children after 10 years of using the device and a high performance rate was observed in the speech perception tests used.

Several studies presented beneficial results with regards to the auditory perception of speech sounds and to oral language acquisition in implanted children 3-4, 8, but due to many factors that may affect the development of hearing and language of the child who uses the cochlear implant, more research will be necessary to verify and follow the development of these abilities.

\section{References}

1. Northem JL, Downs MP. Audição na Infância. $5^{\mathrm{a}}$ ed. Rio de Janeiro: Guanabara Koogan; 2005.

2. Bevilacqua MC, Costa OA, Martinho ACF. Implante Coclear. In: Ferreira LP, Befi-Lopes DM, Limongi SCO. Tratado de Fonoaudiologia. São Paulo: Roca; 2005. p. 75161.

3. Haensel J, Engelke JC, Ottenjann W, Westhofen M. Long-term results of cochlear implantation in children. Otolaryngol Head Neck Surg. 2005;132(3):456-8.

4. Uziel AS, Sillon M, Vieu A, Artieres F, Piron JP, Daures JP, et. al. Ten-year follow-up of a consecutive series of children with multichannel cochlear implants. Otol Neurotol. 2007;28(5):615-28.

5. Moret ALM, Bevilacqua MC, Costa OA. Implante coclear: audição e linguagem em crianças deficientes auditivas prélinguais. Pró-Fono. 2007;19(3):195-304.

6. Santana AP. O processo de aquisição da linguagem: estudo comparativo de duas crianças usuárias de implante coclear. Distúrb Comun. 2005;17(2):233-43.

7. Nicholas JG, Geers AE. Will they catch up? The role of age at cochlear implantation in the spoken language development of children with severe to profound hearing loss. J Speech Lang Hear Res. 2007;50(4):1048-62.

8. Wu JL, Lin CY, Yang HM, Lin YH. Effect of age at cochlear implantation on open-set word recognition in Mandarin speaking deaf children. Int $\mathrm{J}$ Pediatr Otorhinolaryngol. 2006;70(2):207-11.

9. Flipsen P Jr, Colvard LG. Intelligibility of conversational speech produced by children with cochlear implants. J Commun Disord. 2006;39(2):93-108.

10. Stuchi RF, Nascimento LT, Bevilacqua MC, Neto RVB. Linguagem oral de crianças com 5 anos de uso do implante coclear. Pró-Fono. 2007;19(2):167-76.

11. Nikolopoulos TP, Archbold SM, O'Donoghue GM. Does cause of deafness influence outcome after cochlear implantation in children? Pediatrics. 2006;118(4):1350-56.

\section{Conclusion}

The cochlear implant as a treatment for prelingual hearing impaired individuals is highly effective; however, several factors correlate, influencing the performance with the device. We observed highly satisfactory performance in all procedures, which shows the importance of cochlear implants in the development of auditory abilities of hearing impaired individuals.
12. Bakhshaee M, Ghasemi MM, Shakeri MT, Razmara N, Tayarani H, Tale MR. Speeh development in children after cochlear implantation. Eur Arch Otorhinolaryngol. 2007;264(11):1263-66.

13. Yucel E, Sennaroglu G. Is psychological status a determinant of speech perception outcomes in highly selected good adolescent cochlear implant users? Int J Pediatr Otorhinolaryngol. 2007;71(9):1415-22.

14. Beadle EA, McKinley DJ, Nikolopoulos TP, Brough J, O'Donoghue GM, Archbold SM. Long-term functional outcomes and academic-occupational status in implanted children after 10 to 14 years of years of cochlear implant use. Otol Neurotol. 2005;26(6):1152-60.

15. Lacerda AP. Audiologia Clínica. Rio de Janeiro: Guanabara Koogan; 1976.

16. Valente SLO. Elaboração de listas de sentenças construídas na língua portuguesa [dissertation]. São Paulo (SP): Pontifica Universidade Católica; 1998.

17. Delgado EMC, Bevilacqua MC. Lista de palavras como procedimento de avaliação da percepção dos sons da fala para crianças deficientes auditivas. Pró-Fono. 1999;11(1):59-64.

18. Neter J, Kutner MH, Nachtsheim CJ, Wasserman W. Appied Linear Statistical Models. 4th ed. Chicago: Irwin; 1996.

19. Taitelbaum-Swead R, Kishon-Rabin L, Kaplan-Neeman R, Muchnik C, Kronenberg J, Hildesheimer M. Speech perception of children using Nucleus, Clarion or Med-El cochlear implants. Int $\mathrm{J}$ Pediatr Otorhinolaryngol. 2005;69(12):1675-83.

20. Frederigue NB. Reconhecimento de padrões auditivos de freqüência e de duração em crianças usuárias de implante coclear muticanal [tese]. São Paulo (SP): Instituto de Psicologia, Universidade de São Paulo; 2006. 